\title{
Upaya Peningkatan Teknik Smash Bola Voli melalui Model Pembelajaran Inquiry Learning pada Siswa Kelas X SMA Ma'arif Ngawi Tahun Ajaran 2020/2021
}

\author{
Mukarom Alfarezi*, Arief Nur Wahyudi, Andy Widhiya Bayu Utomo \\ Pendidikan Jasmani Kesehatan dan Rekreasi, STKIP Modern Ngawi, Indonesia \\ *mukaromalfarezi45.ar@gmail.com
}

\begin{abstract}
Abstrak
Tujuan penelitian ini untuk mengetahui peningkatan hasil belajar bola voli teknik smash pada siswa kelas X SMA Ma'arif Ngawi melalui model pembelajaran Inquiry Learning. Penelitian ini dilakukan di SMA Ma'arif ngawi kelas X sebanyak 16 siswa. Jenis penelitian ini adalah Penelitian Tindakan Kelas (PTK) yang dilakukan sebanyak 2 (dua) siklus masing-masing tiap siklus dua kali pertemuan. Teknik pengumplan data ini mengunggkan observasi dan tes. Berdasarkan hasil pelaksanaan tes awal, 62,5\% siswa tidak tuntas atau sebanyak 10 siswa, sehingga dilakukan perbaikan pada siklus I untuk memperbaik nilai ketuntasan siswa. Pada siklus I 56,2\% siswa tuntas dalam pelaksanaan pembelajaran atau sebnyak 9 siswa yang tuntas. Pada siklus II mengalami peningkatan yang baik 15 siswa tuntas dalam melaksanakan pembelajaran atau sebanyak $93,75 \%$ yang tuntas. Jadi terbukti bahwa penggunaan model pembelajaran Inquiry Learning mampu meningkatkan hasil belajar siswa pada pembelajaran bola voli teknik smash.
\end{abstract}

Kata kunci: model inquiry learning, peningkatan smash voli, teknik smash.

Dikirim: 27 Juni 2021

Direvisi: 02 Juli 2021

Diterima: 06 Juli 2021

Identitas Artikel:

Alfarezi, M., Wahyudi, A. N., \& Utomo, A. W. B. (2021). Upaya Peningkatan Teknik Smash Bola Voli melalui Model Pembelajaran Inquiry Learning pada Siswa Kelas X SMA Ma'arif Ngawi Tahun Ajaran 2020/2021. Jurnal Ilmu Pendidikan (JIP) STKIP Kusuma Negara, 13(1), 84-91.

\section{PENDAHULUAN}

Pendidikan jasmani adalah suatu proses pembelajaran yang melalui aktivitas fisik atau jasmani untuk mengembangkan keterampilan motorik dan pengetahuan gaya hidup sehat (Mustafa, Winarno \& Supriyadi, 2019). Dalam pembelajaran pendidikan jasmani tidak hanya mengembangkan keterampilan motorik saja namun juga dapat mengembangkan aspek kesehatan, sosial, dan mengembangkan sikap kerjasama dalam suatu kelompok permainan (Paramitha \& Anggara, 2018). Melalui pembelajaran pendidikan jasmani juga dapat membantu siswa mengembangkan kemampuan fisik, pembiasaan pola hidup sehat serta dapat membentuk karakter (emosional, mental dan sosial) (Lengkana \& Sofa, 2017).

Olahraga adalah kegiatan yang dilakukan oleh manusia untuk memelihara kesehatan dan memperkuat otot tubuh. Didalam olahraga masing-masing mempunyai tujuan tertentu misalnya, olahraga prestasi yaitu olahraga yang didesain dan dikelola khusus secara professional dengan tujuan untuk mencapai prestasi optimal pada cabang olahraga tertentu (Setiawan \& Faza, 2019). Olahraga rekreasi adalah olahraga yang dilakukan untuk bersenang-senang, bersantai, dilakukan untuk peyegeran kembali jasmani dan rohani dan dilakukan secara tidak formal dari 
segi peraturan dan sarana yang digunakan (Nababan, Winarno \& Supriyadi, 2018). Sedangkan olahraga pendidikan ialah olahraga yang dilaksanakan didalam ruang lingkup pendidikan untuk memperoleh aspek pengetahuan, keterampilan, kesehatan, dan kebugaran jasmani (Rahman, Gani \& Achmad, 2020).

Permainan dan olahraga yang digemari siswa adalah permainan bola besar, salahsatunya adalah permainan bola voli, permainan bola voli salah satu olahraga yang terdapat didalam materi pembelajaran Pendidikan Jasmani, Olahraga, dan Kesehatan (PJOK). Di dalam permainan bola voli ada banyak peraturan dan teknikteknik, adapun peraturanya sudah ditetapkan oleh Persatuan Bola Voli Seluruh Indonesia (PBVSI). Salah satu teknik yang ada di permainan bola voli adalah teknik smash, teknik smash merupakan pukulan yang kuat terhadap bola dan diarahkan untuk melakukan serangan terhadap lawan untuk mendapatkan poin guna memenangkan pertandingan (Kirom, 2017). Teknik smash merupakan suatu teknik yang memukul bola dengan sangat keras dari atas ke bawah dan menukik ke dalam area musuh atau lawan untuk mendapatkan poin (Asnaldi, 2020).

Dalam pembelajaran PJOK materi bola voli, masih banyak peserta didik yang belum mampu menguasai teknik smash bola voli, karena kurangnya pemahaman siswa dalam permainan bola voli. Di level tingkat SMA pada umumnya siswa memiliki postur yang memadai, seperti tinggi badan, panjang tungkai, panjang lengan, postur tersrbut sangat mendukung untuk melakukan permainan bola voli khususnya pada teknik smash. Struktur yang bagus tersebut perlu didorong dengan mencari cara terkait pembelajaran PJOK khususnya kemampuan teknik smash sehingga dapat membantu terlaksananya pembelajran dengan baik dan bisa tuntas.

Hasil tes praktik yang dilakukan di SMA Ma'arif Ngawi Kelas X menunjukkan banyak siswa 62,5\% mendapatkan nilai di bawah 75 dalam mempraktekkan teknik smash bola voli, hanya siswa yang memang mengikuti latihan bola voli di klub luar sekolah yang cenderung mendominasi. Serta dalam pembelajaran tersebut guru menggunakan model pembelajaran yang menurut peneliti kurang efektif untuk meningkatkan pembelajaran. Artinya tingkat ketuntasan belum tercapai semuanya, maka dari itu untuk menigkatkan hasil belajar teknik smash bola voli pada siswa perlu didorong agar dapat mempraktekkan teknik smash bola voli harus didasarkan pada cara dan penguasaan praktik smash bola voli yang tepat. Sehingga harus ada pendekatan pembelajaran yang tepat yang dapat mengajak siswa untuk aktif mengikuti pembelajaran PJOK teknik smash.

Di SMA Ma'arif Ngawi pada pembelajaran PJOK teknik smash, guru PJOK pada saat pembelajaran berlangsung menggunakan model pembelajaran discovery learning. Model pembelajran discovery learning adalah model pembelajaran yang melibatkan peserta didik dalam proses kegiatannya melalui tukar pendapat, diskusi, dan mencoba sendiri agar siswa dapat menemukan sendiri solusi permasalahan yang didapatkan (Sulfemi, 2019). Artinya didalam pembelajaran tersebut, siswa harus belajar sendiri dalam melaksanakan pembelajaran, sedangkan dalam melaksanakan praktek teknik smash guru perlu melakukan pendampingan lebih lanjut agar siswa lebih paham dalam mempelajari teknik smash bola voli. Di dalam kurikulum 2013 banyak sekali model pembelajaran yang menjadi bahan rujukkan salah satunya ialah Inquiry Learning. Inquiry Learning ialah model pembelajaran yang mengajak siswa untuk memancing mengajukan pertanyaan dan menarik kesimpulan atas pengalaman dan kegiatan praktis serta mengajak siswa untuk berfikir kritis (Ulandari, Putri, Ningsih \& Putra, 2019). Dengan model 
pembelajaran ini diharapkan siswa akan cenderung lebih dekat dengan guru, guru lebih banyak menerima umpan balik dari siswa, siswa lebih aktif dan senang dalam mengikuti pembelajaran karena siswa tidak takut lagi dalam mengajukan sebuah pertanyaan yang menurut siswa kurang paham dalam materi pembelajaran yang diterima. Penggunaan model pembelajaran ini juga pernah dilakukan oleh Aswar (2018) dalam upaya meningkatkan Belajar Menggiring Bola Pada Permainan Sepak Bola Kelas V B SDN Kapota Yudha Makasar, penelitian tersebut menyatakan bahwa dari 36 siswa pada ranah psikomotor rata-rata siswa memperoleh nilai 80,21 atau sebanyak 32 siswa $(88,88 \%)$ yang tuntas, sedangkan yang tidak tuntas hanya 4 siswa $(11,12 \%)$, yang artinya telah mencapai ketuntasan dalam melaksanakan pembelajaran menggunakan model pembelajaran inquiry learning, dengan menggunakan model pembelajaran tersebut siswa lebih aktif dalam proses pembelajaran, siswa juga memberikan respon yang positif terhdap model pembelajaran tersebut.

Berdasarkan uraian tersebut, maka peneliti mencoba menggunakan model pembelajaran Inquiry Learning dalam meningkatkan belajar teknik smash bola voli kelas X di SMA Ma'arif Ngawi.

\section{METODE PENELITIAN}

Jenis penelitian ini menggunakan Penelitian Tindakan Kelas (PTK), penelitian ini dilakukan sebanyak dua siklus yang masing-masing terdiri dari dua pertemuan. Pada pertemuan pertama peneliti memberikan materi dan aktivitas belajar. Sedangkan pada pertemuan kedua, memberikan pengulangan materi dan pemantapan aktivitas belajar keterampilan smash bola voli.

Waktu pelaksanaan penelitian ini dilakukan sebanyak 60 hari, terhitung sejak 19 Januari 2021 sampai dengan 20 Maret 2021. Penelitian ini dilaksanakan di SMA Ma'arif Ngawi kelas X tahun ajaran 2020/2021. Subjek peneltian ini adalah kelas $\mathrm{X}$ sebanyak 16 siswa.

Teknik pengumpulan data ini menggunakan Observasi dan Tes. Desain penelitian ini menggunakan 4 (empat) tahapan. Pertama, tahap perencanaan atau rancangan awal. Pada tahap perencanaan, peneliti menyusun rencana tindakan, membuat instrument penelitian yang digunakan selama pembelajaran dan membuat tujuan yang akan dicapai pada saat pembelajaran. Kedua, tahap pelaksanaan. Kegiatan pelaksanaan yaitu menerapkan model pembelajaran inquiry learning dalam pembelajaran PJOK materi bola voli teknik smash. Kegiatan pelaksanaan dilakukan pada saat pembelajaran PJOK dimana peneliti adalah guru PJOK itu sendiri. Ketiga, tahap evaluasi atau observasi. Observasi dilakukan pada siswa kelas X SMA Ma'arif Ngawi. Obeservasi dilakukan berdasarkan desain penelitian yang telah dibuat oleh peneliti. Obesrvasi atau pengamatan yang dilakukan peneliti adalah upaya untuk membangun tingkat pemahaman siswa materi bola voli teknik smash sekaligus mengamati dampak penerapan model pembelajaran inquiry learning. Keempat, tahap refleksi. Refleksi yaitu mengkaji dampak dari penerapan model pembelajaran inquiry learning yang telah dilakukan, dan memperhatikan hasil dari lembar penilaian yang telah diisi oleh peneliti.

Penelitian ini dinyatakan berhasil apabila telah mencapai $85 \%$ atau rata-rata mendapatkan Kriteria Ketuntasan Minimun (KKM) yaitu 75. Untuk tercapainya penelian tersebut dapat dilihat pada Tabel 1. 
Tabel 1. Rentang Skor Penilaian

\begin{tabular}{cccc}
\hline No & Nilai & Kriteria & Keterangan \\
\hline 1 & $86-100$ & Sangat Baik & Tuntas \\
2 & $75-85$ & Baik & Tuntas \\
3 & $61-74$ & Cukup & Tidak Tuntas \\
4 & $\leq 60$ & Kurang & Tidak Tuntas \\
\hline
\end{tabular}

\section{HASIL PENELITIAN}

Berikut adalah hasil Observasi dan tes keterampilan teknik smash bola voli yang dilakukan untuk mengetahui dan mengukur seberapa besar keterampilan siswa dalam melakukan smash bola voli sebelum di berikan tindakan berupa model pembelajaran inquiry learning.

\begin{tabular}{|c|c|c|c|}
\hline No & Kriteria & Jumlah Siswa & Persentase \\
\hline 1 & Tuntas & 5 & $31,25 \%$ \\
\hline 2 & Tidak Tuntas & 11 & $68,75 \%$ \\
\hline \multicolumn{3}{|c|}{ Rata-rata Nilai } & 66 \\
\hline
\end{tabular}

Hasil evaluasi pembelajaran smash bola voli sebelum menggunakan model pembelajaran inquiry learning diperoleh siswa yang tuntas sebanyak 5 siswa $(31,25 \%)$, sedangkan siswa yang tidak tuntas sebesar 11 siswa $(68,75 \%)$.

Berdasarkan data tersebut menunjukan bahwa sebagian besar siswa dalam melakukan pembelajaran bola voli teknik smash masih rendah atau belum tuntas. Hasil ini ditemukan terdapat 11 dari 16 siswa yang nilainya masih di bawah KKM yaitu 75 hanya 5 siswa yang tuntas dalam melaksanakan pembelajaran atau ratarata nilai siswa yaitu 66. Untuk memperbaiki dan meningkatkan hasil belajar yaitu melakukan pendekatan melalui model pembelajaran inquiry learning.

Berdasarkan pada hasil observasi dan evaluasi awal siswa belum mencapai indikator keberhasilan secara klasikal. Sebagai bentuk refleksi yang menjadi pertimbangan untuk melakukan perbaikan tindakan pada siklus I yaitu: (1) siswa kurang fokus dalam melaksankan pembelajaran bahkan terlihat siswa belum antusias dan aktif dalam melaksanakan pembelajaran; (2) siswa belum terlihat percaya diri dalam melakukan gerakan teknik smash bola voli; (3) siswa belum begitu paham betul mengenai teknik smash yang diberikan oleh guru PJOK.

\section{Hasil Siklus I}

Berdasarkan hasil tes observasi awal pembelajaran bola voli teknik smash yang telah dilakukan bahwa nilai rata-rata siswa kelas X SMA Ma'arif masih dibawah KKM sehingga perlu dilakukan tindakan lebih lanjut untuk meningkatkan ketuntasan belajar siswa. Berikut adalah hasil tes pembelajaran bola voli teknik smash menggunakan model pembelajaran inquiry learning pada siklus I.

Berdasarkan hasil tindakan tes yang telah dilakukan maka didapatkan nilai pada siklus I. Siswa yang tuntas dalam pembelajaran bola voli teknik smash sebanyak 7 siswa $(43,75 \%)$. Sedangkan yang tidak tuntas sejumlah 9 siswa $(56,25 \%)$. Pada pembelajaran bola voli teknik smash, Rata-rata siswa mendapatkan nilai 73,30. 
Tabel 3. Hasil Tes Pembelajaran Siklus I

\begin{tabular}{clcc}
\hline \multirow{2}{*}{ No } & \multirow{2}{*}{ Kriteria } & $\begin{array}{c}\text { Jumlah } \\
\text { Siswa }\end{array}$ & $\begin{array}{c}\text { Persentas } \\
\text { e }\end{array}$ \\
\hline 1 & Tuntas & 7 & $43,75 \%$ \\
2 & Tidak Tuntas & 9 & $56,25 \%$ \\
\hline \multicolumn{3}{c}{ Rata-rata Nilai } & 73,30 \\
\hline
\end{tabular}

Berdasarkan pada hasil observasi dan evaluasi pada siklus I siswa masih belum mencapai indikator keberhasilan secara klasikal. Sebagai bentuk refleksi yang menjadi pertimbangan untuk melakukan perbaikan tindakan pada siklus II yaitu: (1) siswa masih kurang fokus dalam melaksanakan pembelajaran, bahkan sebagian siswa tidak begitu mendengarkan penjelasan materi yang telah diberikan ini karena siswa kurang termotivasi dalam melaksanakan pembelajaran; (2) siswa belum sepenuhnya aktif dan antusisas dalam melaksanakan pembelajaran; (3) siswa masih ragu-ragu dalam melaksanakan praktek gerakan teknik smash bola voli sehingga mengakibatkan gerakan belum maksimal. Oleh karena itu dapat menjadi bahan pertimbangan dan perbaikan pada siklus II.

\section{Hasil Siklus II}

Berdasarkan hasil tes yang telah dilakukan di siklus I pada pembelajaran bola voli teknik smash, bahwa nilai rata-rata siswa kelas X SMA Ma'arif masih dibawah KKM sehingga perlu dilakukan tindakan lebih lanjut pada siklus II untuk meningkatkan ketuntasan belajar siswa. Berikut adalah hasil tes pembelajaran bola voli teknik smash menggunakan model pembelajaran inquiry learning pada siklus II yang dirangkum dalam Tabel 4.

Tabel 4. Hasil Tes Pembelajaran Siklus II

\begin{tabular}{cccc}
\hline No & Kriteria & Jumlah Siswa & Persentase \\
\hline 1 & Tuntas & 15 & $93,75 \%$ \\
2 & Tidak Tuntas & 1 & $6,25 \%$ \\
\hline \multicolumn{3}{c}{ Rata-rata Nilai } & 90 \\
\hline
\end{tabular}

Berdasarkan hasil tindakan tes yang telah dilakukan maka didapatkan nilai pada siklus II. Siswa yang tuntas dalam pembelajaran bola voli teknik smash sebanyak 15 siswa $(93,75 \%)$. Sedangkan yang tidak tuntas sejumlah 1 siswa 6,25\%. Pada pembelajaran bola voli teknik smash, Rata-rata siswa mendapatkan nilai 90. Artinya pada tindakan siklus II ini peneliti telah manyatakan tuntas dalam melaksanakan pembelajaran bola voli teknik smash menggunakan model inquiry learning.

Berdasarkan pada hasil observasi dan evaluasi pada siklus II, sebagai bentuk refleksi yang menjadi pertimbangan untuk melakukan perbaikan dan tindakan untuk menyelesaikan permasalahan-permasalah pada siklus I upaya yang dilakukan mengalami peningkatan, hasil pengamatan sebagai berikut: (1) siswa sangat fokus dan antusias dalam melaksanakan pembelajaran, siswa sangat mendengarkan penjelasan dan materi yang diberikan oleh peneliti atau guru; (2) dalam proses pembelajaran siswa sangat bersungguh-sungguh dalam melaksanakan pembejaran. Siswa sangat percaya diri dalam melakakukan gerakan smash bola voli; (3) siswa 
tidak ragu-ragu lagi dalam melakukan gerakan teknik smash bola voli, sehingga gerakan yang dihasilkan sangat maksimal.

\section{PEMBAHASAN}

Berdasarkan hasil penelitian pada pembelajaran PJOK materi bola voli teknik smash melalui model pembelajaran inqury learning, terbukti bahwa model tersebut dapat meningktkan pembelajaran siswa serta mampu menambah pemahaman yang lebih pada pembelajaran bola voli teknik smash. Hasil penelitian ini juga didukung oleh Aswar (2018) bahwa penggunaan model pembelajaran inquiry learning dapat meningkatkan hasil belajar siswa. Model pembelajaran tersebut membuat siswa lebih aktif, dekat dengat guru, serta dapat berfikir kritis dalam menemukan permasalahan yang dihadapi siswa.

Dengan demikian model pembelajaran inquiry learning, peserta didik dapat memahami materi lebih dalam pada saat guru memberikan materi pembelajaran serta meningkatkan kemampuan komunikasi siswa kepada guru. Komunikasi yang intens terhadap murid dengan guru dapat memberikan pengaruh besar untuk perilaku belajar siswa, semakin guru meningkatkan komunikasinya dengan siswa maka akan semakin memperbaiki perilaku siswa.

Selanjutnya pada pelaksanaan siklus I memperoleh hasil 9 siswa $(56,25 \%)$ yang tuntas dalam melaksanakan pembelajaran bola voli teknik smash. Sedangkan yang tidak tuntas sejumlah 7 siswa $(43,75 \%)$. Dari ketuntasan belajar tersebut rata-rata siswa memperoleh nilai 73,30. Hal ini dikatakan belum tuntas pada siklus I, karena nilai ketuntasan atau penelitian dikatakan berhasil minimal memperoleh nilai 75 . Maka hal tersebut peneliti melanjutkan pada siklus II dengan tujuan untuk lebih mendorong siswa dalam memahami pembelajaran bola voli teknik smash dan meningkatkan hasil belajar siswa.

Pada pelaksanaan siklus II siswa mengalami peningkatan belajar yang baik, pada siklus II ditemukan siswa yang tuntas dalam melaksanakan pembelajaran bola voli teknik smash sebanyak 15 siswa $(93,75 \%)$ dan yang tidak tuntas hanya 1 siswa $(6,25 \%)$. Dari data tersebut rata-rata siswa mendapatkan nilai 90. Pada siklus ini telah dinyatakan tuntas dalam pelaksanaan pembelajaran bola voli teknik smash. Dan penelitian ini sudah dinyatakan selesai atau menghentikan penelitian ini, karena siswa rata-rata sudah memenuhi KKM yaitu 75 . Hal ini sesuai yang diharapkan oleh peneliti bahkan melebihi kriteria minimal ketuntasan yang diharapkan peneliti. Siswa yang tidak tuntas pada siklus II ini, peneliti menyerahkan siswa tersebut kepada guru PJOK Kelas X SMA Ma'arif Ngawi untuk di bimbing lebih lanjut dalam memahami pembelajaran bola voli teknik smash.

Dari data tersebut, terbukti bahwa penggunaan model pembelajaran inquiry learing dapat meningkatkan hasil belajar bola voli teknik smash. Hal ini dibuktikan dari hasil nilai siswa yang meningkat baik dari hasil belajar pada siklus I dan siklus II yang telah berhasil mencapai nilai KKM, yaitu 75 .

\section{SIMPULAN}

Berdasarkan penelitian tindakan kelas yang dilakukan terhadap siswa kelas X SMA Ma'arif Ngawi pada pembelajaran bola voli teknik smash melalui model pembelajaran inquiry learning, terbukti dapat meningkatkan hasil belajar bola voli 
teknik smash. Hal ini dibuktikan dari observasi awal siswa belum tuntas dalam pelaksanaan pembelajaran bola voli, setelah dilakukan pada siklus I dan II siswa mengalami peningkatan yang baik pada pembelajaran bola voli teknik smash. Hal ini sesuai apa yang diharapkan oleh peneliti.

\section{UCAPAN TERIMA KASIH}

Peneliti mengucapkan terimkasih banyak kepada keluarga besar SMA Ma'arif Ngawi yang telah menerima peneliti untuk memberikan kesempatan mengadakan penelitian khususnya pada siswa kelas X SMA Ma'arif Ngawi tentang penerapan model pembelajaran inquiry learning. Peneliti berterimakasih kepada bapak Arif Nur Wahyudi dan bapak Andy Widhiya Bayu Utomo yang telah membimbing dan memberikan arahan kepada peneliti untuk kelancaran melaksanakan penelitian. Peneliti juga berterimakasih banyak kepada guru PJOK SMA Ma'arif Ngawi bapak Ali Munir yang bersedia membantu peneliti melaksanakan pembelajaran menggunakan model pembelajran inquiry learning khususnya kelas $\mathrm{X}$.

\section{REFERENSI}

Asnaldi, A. (2020). Hubungan Kelentukan dan Daya Ledak Otot Lengan terhadap Ketepatan Smash Bolavoli. Physical Activity Journal, 1(2), 160. https://doi.org/10.20884/1.paju.2020.1.2.2556

Aswar, A. (2018). Upaya Meningkatkan Hasil Belajar Menggiring Bola pada Permainan Sepakbola melalui Model Pembelajaran Inkuiri Siswa Kota Makassar. Sportive: Journal of Physical Education, Sport and Recreation, 1(2), 36-50. https://doi.org/10.26858/sportive.v1i2.5635

Kirom, A. (2017). Implentasi Model Pembelajaran Discovery Learning dalam Peningkatan Keterampilan Siswa Bermain Bolavoli Pada Matapelajaran PJOK di SMA Negeri Blega Bangkalan. Buana Pendidikan: Jurnal Fakultas Keguruan dan Ilmu Pendidikan, 13(24), 99-108. https://doi.org/10.36456/bp.vol13.no24.a761

Lengkana, A. S., \& Sofa, N. S. N. (2017). Kebijakan Pendidikan Jasmani dalam Pendidikan. Jurnal Olahraga, 3(1), 1-12. https://doi.org/10.37742/jo.v3i1.67

Mustafa, P. S., Winarno, M. E., \& Supriyadi, S. (2019). Penilaian Pendidikan Jasmani, Olahraga, dan Kesehatan pada Sekolah Menengah Pertama Negeri Kota Malang. Jurnal Pendidikan: Teori, Penelitian, Dan Pengembangan, 4(10), 1364-1379. https://doi.org/http://dx.doi.org/10.17977/jptpp.v4i10.12845

Nababan, M. B., Dewi, R., \& Akhmad, I. (2018). Analisis Pola Pembinaan dan Pengembangan Olahraga Rekreasi di Federasi Olahraga Rekreasi Masyarakat Indonesia Sumatera Utara Tahun 2017. Jurnal Pedagogik Olahraga, 4(1), 3855. https://doi.org/10.22245/jpor.v4i1.11963

Paramitha, S. T., \& Anggara, L. E. (2018). Revitalisasi Pendidikan Jasmani untuk Anak Usia Dini melalui Penerapan Model Bermain Edukatif Berbasis Alam. Jurnal Pendidikan Jasmani dan Olahraga, 3(1), 41. https://doi.org/10.17509/jpjo.v3i1.10612

Rahman, I., Gani, R. A., \& Achmad, I. Z. (2020). Persepsi Siswa pada Pembelajaran Pendidikan Jasmani Olahraga dan Kesehatan Tingkat SMA. Jurnal Pendidikan Olah Raga, 9(2), 144-154. http://dx.doi.org/10.31571/jpo.v9i2.1898 
Setiawan, I., \& Faza, R. U. (2019). Pembangunan Olahraga Ditinjau dari SDI Guna Peningkatan Kualitas Pendidikan Jasmani Berwawasan Konservasi. In Prosiding Seminar Nasional IPTEK Olahraga (SENALOG), 2(1), 1-7.

Sulfemi, W. B. (2019). Penerapan Model Pembelajaran Discovery Learning Meningkatkan Motivasi dan Hasil Belajar Pendidikan Kewarganegaraan. Jurnal Rontal Keilmuan Pancasila dan Kewarganegaraan, 5(1), 17-30. https://doi.org/10.29100/jr.v5i1.1021

Ulandari, N., Putri, R., Ningsih, F., \& Putra, A. (2019). Efektivitas Model Pembelajaran Inquiry terhadap Kemampuan Berpikir Kreatif Siswa pada Materi Teorema Pythagoras. Jurnal Cendekia : Jurnal Pendidikan Matematika, 3(2), 227-237. https://doi.org/10.31004/cendekia.v3i2.99 